\title{
АГРОЕКОЛОГІЧНІ СИСТЕМИ БІОГЕОХІМІЧНИХ ЛАНЦЮГІВ ПОЖИВНИХ ЕЛЕМЕНТІВ
}

\section{Єгорова T. М.}

\section{ВСТУП}

Формування i розвиток аграрної екології зумовлені активним впливом окремих природно-техногенних процесів на якість сільськогосподарської сировини та продукції. За словами академіка О.О. Созінова, агроекологія XXI сторіччя покликана формувати нову філософію агросфери ${ }^{1}$. Таку філософію неможливо сформувати без урахувань процесів біогеохімічних. Звертаючись до «Біогеохімічних нарисів» В.І. Вернадського, неможливо не згадати слова його учня О.С. Ферсмана, який наголошував, що чимало років ідеї B.I. Вернадського не будуть зрозумілими. Пройшло 70 років, але ці слова повною мірою стосуються ідей Вернадського для частини біосфери України, яка використовується (у прямому сенсі цього слова) у сфері виробництва сільськогосподарської продукції.

Агроекологічні наслідки біогеохімічних процесів розкривають системи біогеохімічних ланцюгів хімічних елементів (поживних або токсичних), ланками яких за В.В. Ковальським $є$ гірські породи, природні води, грунти, рослини, харчові продукти та ін. ${ }^{2}$

Вивчення та екологічну оцінку біогеохімічних ланцюгів поживних (есенційних) хімічних елементів як складних багатофакторних систем було започатковано у 1970-х роках у межах одного 3 прикладних напрямів біогеохімії - геохімічної екології. Структура ланцюга окремого хімічного елементу складається 3 окремих ланок: гірських порід, грунтів, води, грунтових мікроорганізмів, рослин природних та сільськогосподарських, кормів тварин та харчових продуктів людини тощо. Усі ланки біогеохімічного ланцюга спряжені між собою та об'єднані процесами природної і техногенної геохімічної міграції, зокрема фізико-хімічної та біогенної. До складу засад геохімічної екології входить взаємозв'язок між особливостями біогеохімічних

${ }^{1}$ Созінов О.О. Агросфера України у XXI столітті. Вісник Національної академії наук України. 2001. № 10. С. 15.

2 Ковальский В.В. Геохимическая экология. Москва : Наука, 1974. С. 130 ; Єгорова Т.М., Ісаєнко В.М. Основи біогеохімії : навчальний посібник. Київ : НАУ, 2005. C. 98 . 
ланцюгів і фізіологічним станом живих організмів (рослин, тварин, худоби чи людини) на територій їх існування. ${ }^{3}$

Практика досліджень земель сільськогосподарського призначення доволі часто оцінює багатофакторну біогеохімічну систему лише за двома параметрами: NPK грунту - врожайність сільськогосподарської культури. Такі граничні обмеження пояснюються фактичною відсутністю у складі сучасних аграрних досліджень як агроландшафтної систематизації земель сільськогосподарського призначення, так і сполученої інформації про хімічний склад гірських порід, грунтів, рослин вод, харчових раціонів тварин і населення. Такий полегшений підхід до оцінки орних земель дає змогу вирішувати головні антропоцентричні завдання вирощування сільськогосподарської продукції, але не дає можливості виявити сутності багатьох агроекологічних проблем, а відповідно, виокремити шляхи їх вирішення.

Наші багаторічні еколого-геохімічні і біогеохімічні дослідження агроландшафтів України ${ }^{4}$ дали змогу конкретизувати поняття біогеохімічних ланцюгів поживних елементів як окремих систем, спряжених у межах агроландшафту ланок «гірські породи - трунти води - жива речовина рослин природних та сільськогосподарських», які пов'язані між собою процесами біогенної і фізико-хімічної природнотехногенної міграції біофільних (поживних) хімічних елементів.

Вивчення біогеохімічних ланцюгів у межах орних земель не відноситься до пріоритетів аграрної науки України. Вочевидь, що така інформація здатна виявити та висвітлити недосліджені елементи негативного впливу сільського господарства на стан довкілля додатково до тих, що широко висвітлює сучасна агроекологія. Окрім цього, фактично відсутні і методологія, і методика таких досліджень на відміну від методів дослідження земель сільськогосподарського призначення, які «узаконені» роботами аграріїв у середині минулого століття ${ }^{5}$.

Представлені дослідження висвітлюють особливості екологічного оцінювання біогеохімічних ланцюгів поживних елементів як окремих природно-техногенних систем та їх значення для підвищення якості продукції рослинництва і збалансованого природокористування в агросфері.

${ }^{3}$ Ковальский В.В. Геохимическая экология. Москва : Наука, 1974. С. 130-150 ; Єгорова Т.М., Ісаєнко В.М. Основи біогеохімії : навчальний посібник. Київ : НАУ, 2005. C. 98-101.

${ }_{4}$ Сгорова Т.М. Екологічна геохімія агроландшафтів України : монографія / за наук. ред. О.І. Фурдичка. Київ : ДІА, 2018. С. 140-204.

Доспехов Б.А. Методика полевого опыта (с основами статистической обработки результатов исследований). Москва : Агропромиздат, 1985. С. 9-18. 


\section{1. Особливості біогеохімічних досліджень екології агросфери}

Біогеохімічні дослідження агросфери спроможні суттєво посилити наукове обгрунтування широкого кола сучасних проблем екології. стосується підвищення якості сільськогосподарської продукції, удосконалення місцевих сівозмін, обгрунтування методів точкового землеробства, медико-екологічних оцінок щодо поширення і запобігання ендемічним фітопатологіям і мікроелементозам. Вагомою екологічною проблемою сучасної науки $є$ виокремлення природного і техногенного складників у процесах функціонування ноосфери. Існуючі підходи до ідентифікації гранично допустимих концентрацій як єдиного критерію техногенного забруднення земель сільськогосподарського призначення не мають найменшого наукового обгрунтування в межах геолого-геохімічних наук. Агроекологічне значення системи біогеохімічних ланцюгів полягає у можливості визначення агротехногенних деформацій орних земель в існуючих умовах сільськогосподарської діяльності. По суті, це визначення рівня та складу хімічної деградації орних земель. Такі зміни ми сформулювали як агротенногенні трансформації агроландшафтів.

Вагомим елементом методики біогеохімічних досліджень $\epsilon$ інформативна оцінка переходу поживних біофільних елементів у ланцюзі «гірські породи - води - грунти - природні рослини та сільгоспкультури», що потребує сполучених статистичних оцінок їх умісту в ланцюзі певного агроландшафту як основи для розрахунків групи біогеохімічних коефіцієнтів. Агроекологічне оцінювання біогеохімічних ланцюгів проводиться на підставі їх параметрів, коефіцієнтів та критеріїв.

Для оцінки антропогенних змін довкілля широко застосовуються порівняння послідовностей (ранжованих рядів) фонових рівнів умісту хімічних елементів у грантах і рослинах із кларками як глобальними природними нормами у біосфері. Порушення послідовностей часто вважають ознакою техногенного забруднення i суттєвого антропогенного тиску на компонент довкілля. Значення кларків хімічних елементів $\epsilon$ результатом узагальнення світових даних провідними науковцями впродовж XX ст.: Ф. Кларком, О.П. Виноградовим, О.О. Бєусом, О.І. Перельманом, Г. Боуеном, А. Кабата-Пендіас, В.В. Івановим ${ }^{7}$.

6 Сгорова Т.М. Біогеохімічні пріоритети агроекологічних досліджень. Агроекологічний журнал. 2017. № 1. С. 29.

${ }^{7}$ Иванов В.В. Экологическая геохимия элементов : справочник : в 6 кн. / под. ред. Э.К. Буренкова. Москва : Недра, 1994. Кн. 1. С. 20-29 ; Сгорова Т.М., Ісаєнко В.М. Основи біогеохімії : навчальний посібник. Київ : НАУ, 2005. С. 23-33. 
У земній корі зниження кларкового вмісту основних біофільних та поживних хімічних елементів від 53300 до 1,2 мг/кг відповідає послідовності $\mathrm{Fe}-\mathrm{Ca}-\mathrm{K}-\mathrm{P}-\mathrm{Mn}-\mathrm{Ba}-\mathrm{Zn}-\mathrm{Cu}-\mathrm{Co}-\mathrm{N}-\mathrm{Mo}$; в осадових породах від 46600 до 1,5 мг/кг - Fe - Ca $-\mathrm{K}-\mathrm{Ba}-\mathrm{Mn}-\mathrm{P}-\mathrm{N}$ - $\mathrm{Zn}-\mathrm{Cu}-\mathrm{Co}-\mathrm{Mo}$; у грунтах від 40000 до 1,2 мг/кг - Fe - Ca $-\mathrm{K}-\mathrm{Mn}$ - $\mathrm{N}-\mathrm{P}-\mathrm{Zn}-\mathrm{Ba}-\mathrm{Cu}-\mathrm{Co}-\mathrm{Mo}$; у золі континентальних рослин від 70000 до 15 мг/кг - P - K - Ca $-\mathrm{Fe}-\mathrm{Mn}-\mathrm{Zn}-\mathrm{Ba}-\mathrm{N}-\mathrm{Cu}-\mathrm{Mo}-\mathrm{Co}$; у континентальних водах від 20,4 до 0,0014 мг/дм ${ }^{3}-\mathrm{Ca}-\mathrm{K}-\mathrm{Fe}-\mathrm{N}-$ $\mathrm{Mn}-\mathrm{P}-\mathrm{Ba}-\mathrm{Zn}-\mathrm{Cu}-\mathrm{Mo}-\mathrm{Co}$. Безліч досліджень присвячено поясненню існуючих закономірностей у поширенні хімічних елементів, між тим указані послідовності розглядаються як природні біосферні норми для хімічних елементів. Зміна послідовностей інтерпретується як прояв техногенного забруднення певного компоненту довкілля. Наприклад, на підставі невідповідності ранжованому ряду елементів для золи континентальних рослин на території Ростовської обл. було встановлено забруднення зерна та соломи пшениці $\mathrm{Sr}, \mathrm{Mg}$ під впливом териконів у агроландшафтах, які не захищені лісосмугами ${ }^{8}$.

Біогеохімічні дослідження впливу сільськогосподарської діяльності на довкілля дають змогу розширити методологію таких оцінок за рахунок трьох груп геохімічних коефіцієнтів під час застосування розроблених нами критеріїв їх агроекологічного оцінювання.

1. Особливості перерозподілу поживних елементів у верхніх ланках біогеохімічного ланцюга висвітлюють коефіцієнти біогенної міграції, введені в науку О.І. Перельманом9. Розраховують Ах за співвідношенням вмісту елементі у золі рослини до його валового вмісту у гумусовому горизонті грунту або кларку літосфери за відсутності даних по грунту. Для континентальних рослин біосфери Ах отримані А.І. Перельманом і В.В. Добровольським ${ }^{10}$. Інтенсивність переходу у рослини основних поживних елементів знижується у такій послідовності відповідно до глобальних значень Ах: Р (75) - Мо (18) $\mathrm{Zn}(11,8)-\mathrm{Mn}(7,5)-\mathrm{K}(6)-\mathrm{Cu}(4,2)-\mathrm{Ca}(1)-\mathrm{Co}(0,8)-\mathrm{N}(0,3)-\mathrm{Fe}$ $(0,2)$. Ці глобальні значення грають роль маркерів, що дають змогу надати агроекологічну оцінку найбільш динамічній частині

8 Кокин А.В., Слюсарь А.В., Шумакова Г.Е. Сохранение информации о первичной распространённости химических элементов на разных уровнях организации вещества. Достижения и проблемы современной науки : материалы XXII междун. науч.-практич. конф., г. Санкт-Петербург, 4 августа 2017 г. СанктПетербург, 2017. С. 10.

9 Перельман А.И. Геохимия ландшафтов. Москва : Высшая школа, 1975. С. 36-37.

${ }^{10}$ Єгорова Т.М., Ісаєнко В.М. Основи біогеохімії : навчальний посібник. Київ : НАУ, 2005. С. 44-49 ; Єгорова Т.М. Екологічна геохімія агроландшафтів України : монографія / за наук. ред. О.І. Фурдичка. Київ : ДІА, 2018. С. 67-69. 
біогеохімічного ланцюга поживного елементу та розрізняють групи поживних елементів-біофілів $(\mathrm{Ax}>1)$ та елементів-біофобів $(\mathrm{Ax}<1)$.

Оцінити Ах на землях сільськогосподарського призначення надають методичні можливості виявлення відхилень існуючих біогеохімічних ланцюгів порівняно від біосферних закономірностей та порівняння характеру природних i техногенних процесів біогенної міграції поживних елементів. Перевищення глобальної норми Ах свідчить про ріст біофільності елементу, причинами якого можуть бути як природні концентраційні особливості рослин чи перезволоженість грунту, так i агротехногенна нестача відповідного поживного елементу у грунтовому покриві, що інтенсифікує захисні біохімічні процеси рослини. У разі значення, що суттєво нижче глобальної норми, та переходу елементу від біофілів до біофобів поживне значення елементу фактично втрачається для харчових ланок системи: харчової сировини, худоби, тварин, людини. За цих умов формується стійка біогеохімічна харчова нестача відповідного поживного елементу, яка має постійно поповнюватися за рахунок додаткових біологічних речовин, що містять відповідний поживний елемент.

Треба зазначити, що у практиці агрохімічних досліджень доволі часто коефіцієнт біологічного поглинання (Ax) підміняють співвідношенням умісту елементу в сухій речовині до його вмісту у рухомій формі орного шару грунту, що іноді називають коефіцієнтом переходу (КПх). Таке співвідношення має доволі локальну значимість $\mathrm{i}$ фактично не має оцінок з екологічного погляду.

1. Перерозподіл та характер процесів фізико-хімічної міграції поживних елементів у ланках біогеохімічного ланцюга визначають та оцінюють за кларком концентрації (ККі), уведеним у науку B.I. Вернадським ${ }^{11}$. Кларк концентрації вказує на основний напрям процесів переміщення хімічних елементів - концентрація i накопичення у середовищі за ККі $\geq 1$ або розсіювання і винесення із середовища за ККі $\leq 1$. Розраховують ККі за співвідношенням умісту елементу у певній ланці біогеохімічного ланцюга до його відповідного кларку у біосфері: гірських породах, водах, грунтах, континентальній рослинності. Наші агроекологічні дослідження визначили необхідність розрізняти третій рівень процесів фізико-хімічної міграції, який ми визначили як рівноважний за коливання ККі від 0,5 до $1,5^{12}$.

Концентрація поживного елементу у компонентах ланцюга «гірські породи - води - грунти» природного агроландшафту визначає існуючі

\footnotetext{
${ }_{11}^{11}$ Перельман А.И. Геохимия ландшафтов. Москва : Высшая школа, 1975. С. 23-24.

${ }^{12}$ Єгорова Т.М. Еколого-геохімічні процеси міграції кобальту в агроландшафтах України. Вісник аграрної науки. 2014. № 6. С. 59.
} 
біосферні особливості місцевості. За цих умов доцільно підбирати для вирощування такі сільськогосподарські культури, вирощування яких потребує саме визначених елементів геохімічної концентрації. Поживні елементи, яким властиве розсіювання у нижніх ланках біогеохімічного ланцюга, фактично завжди будуть дефіцитними у сільськогосподарській сировині рослинництва. Для забезпечення високої якості такої продукції потрібним $є$ позакореневе живлення культур відповідними хімічними елементами.

У практиці агрохімічних досліджень прийнято застосовувати поняття «важкий метал» у разі перевищення його вмісту порівняно зі значенням гранично допустимої концентрації у грунті. Ця «традиція», по суті, суперечить існуючим геохімічним класифікаціям хімічних елементів. У межах агроекологічних досліджень оцінювання вмісту поживного елементу у грунті (валова та рухома форма знаходження), водах чи сільськогосподарській культурі відносно його гранично допустимої концентрації ми визначаємо як екологічний коефіцієнт концентрації (Кеі $)^{13}$.

3. Природно-техногенні процеси у біогеохімічних системах можуть фіксуватися шляхом кореляційного статистичного аналізу. Від'ємна лінійна кореляція між коефіцієнтами біологічного поглинання та (або) фонового вмісту поживних елементів та глобальними нормами (кларками, Ах, ін.) свідчить про суттєвість трансформаційних процесів. Позитивна лінійна кореляція $(\mathrm{r} \geq 0,5)$ між хімічними параметрами агроландшафтів та біосферними характеристиками вказує на збереження природних закономірностей у функціонуванні біогеохімічних циклів поживних елементів.

\section{2. Системи біогеохімічних ланцюгів агроландшафтів}

\section{Правобережного Лісостепу}

Вивчення біогеохімічних ланцюгів п'яти поживних хімічних елементів (P, Ca, Zn, Co, Мо) проводилося на території земель сільськогосподарського призначення Бузько-Середньодніпровського природно-сільськогосподарського округу Правобережного Лісостепу впродовж 2016-2020 pp. і включало комплекс польових, лабораторних і камеральних досліджень.

Агроекологічне значення досліджених поживних елементів для забезпечення якості сільськогосподарської продукції рослинництва і тваринництва викладено у різноманітних джерелах, включаючи

${ }^{13}$ Єгорова Т.М. Екологічна геохімія агроландшафтів України : монографія / за наук. ред. О.І. Фурдичка. Київ : ДІА, 2018. С. 121. 
й узагальнення автора ${ }^{14}$. Фосфор покращує азотне живлення культур, забезпечує швидкий ріст і розвиток кореневої системи, прискорює дозрівання, поліпшує водний режим, збільшує вміст цукрів і каротину; надлишок фосфору може призвести до токсикозу рослин та міжжилкового хлорозу. Кальцій забезпечує поглинання інших елементів живлення, $є$ необхідним для зростання кореневої системи і запобігання пошкодженням під час збирання. Цинк сприяє підвищенню стійкості рослин до несприятливих кліматичних умов, запобігає передчасному старінню клітин, бере участь у синтезі регуляторів росту, хлорофілу та вітамінів; надлишок цинку призводить до розеткової хвороби у злаків, овочевих і плодових культур, а також знижує врожайність зернових і технічних культур. Агроекологічне значення Мо пов'язане 3 фіксацією атмосферного азоту, синтезом хлорофілу і вітамінів; нестача Мо у рослинах знижує інтенсивність фотосинтезу, у тварин здатне викликати атеросклероз, ожиріння, артрити. Кобальт сприяє процесам росту і метилування рослин, впливає на інтенсивність дихання і фотосинтез, регулює загальний уміст води у рослинах, забезпечує розмноження бульбашкових бактерій та фіксації ними азоту; за нестачі кобальту у тварин можуть розвиватися анемії.

Дослідження систем біогеохімічних ланцюгів поживних елементів Правобережного Лісостепу зосереджено у межах елементарних агроландшафтів басейнів річок Домантовка і Березанка. Глибинні геолого-геохімічні дослідження засвідчили поширення тут літофільнохалькофільної спеціалізації та ендогенних природних аномалій $\mathrm{P}, \mathrm{Zn}$ та ін. у кристалічних гірських породах та корах вивітрювання Українського щита ${ }^{15}$. У виконанні польових робіт разом 3 автором брали участь співробітники Інституту агроекології i природокористування НААН (Т.П. Сапсай, Ю.М. Терновий), лабораторних робіт - працівники Центральної лабораторії ДП «Українська геологічна компанія» (М.В. Приходько та ін.). Здійсненню досліджень передувало регіональне агроландшафтне картування території площею 5,4 тис кв. км (у межах Сквирського адміністративного p-ну Київської обл., Ружинського p-ну Житомирської обл. та Погребищенського р-ну Вінницької обл.) та детальне картування на площі 20 кв. км (у межах Сквирського району Київської обл.).

${ }^{14}$ Єгорова Т.М. Екологічна геохімія агроландшафтів України : монографія / за наук. ред. О.І. Фурдичка. Київ : ДІА, 2018. С. 188-204.

${ }^{15}$ Комплект карт «Геологія і корисні копалини України», масштаб 1:1 000000 : пояснювальна записка / за ред. Д.Г. Гурського та ін. Київ : УкрДГРІ, 2003. С. 173. 
Агроландшафтне районування цих територій дало змогу виокремити у межах земель сільськогосподарського призначення три типи систем біогеохімічних ланцюгів та відповідних територій. Особливості системи зумовлюють переважаючий генезис та характер природно-техногенних процесів міграції поживних елементів. Визначення генетичної основи та топічної агроландшафтної будови систем базується на класифікації видів геохімічної міграції O.I. Перельмана та функціональному зонуванні геохімічних ландшафтів I.О. Морозової відповідно до відсоткової зрушеності природної структури земель в процесі господарської діяльності ${ }^{16}$. Системи біогеохімічних ланцюгів ми ідентифікуємо як природні (найменш залежні від антропогенно-техногенного впливу за зрушеності природної структури земель до 15\%), техногенно-природі (природні процеси превалюють над антропогенно-техногенними за зрушеності природної структури земель переважно від 25 до 40\%) і техногенні (найбільш залежні від антропогенно-техногенного впливу та зрушеності земель понад 50\%).

\section{1. Природні системи біогеохімічних ланцюгів поживних елементів}

Природні системи біогеохімічних ланцюгів характеризує найнижча ступінь зміни природних процесів міграції хімічних елементів та, відповідно, фізико-хімічних умов життєзабезпечення рослин, тварин, мікроорганізмів. На території Правобережного Лісостепу до таких агроландшафтів відносяться сіножаті та пасовища луків, незручності чагарників, ставки та річки комплексного водогосподарського використання. Дослідження природних біогеохімічних ланцюгів проводилося у межах двох елементарних агроландшафтів.

1. Супераквальний агроландшафт сіножатей i пасовища тераси річки 3 різнотрав'яно-злаковою рослинністю і листяними деревами, лучно-чорноземними грунтами на суглинково-супіщаних алювіальних відкладах у межах вирівняних річкових терас (ПА 1).

2. Елювіально-акумулятивний агроландшафт сіножатей і пасовищ улоговини з різнотрав'яною рослинністю і чагарниками, чорноземами типовими та оглеєними на лесованих суглинках (ПА 2).

Ранжовані ряди фонових значень та коефіцієнтів біологічного поглинання у компонентах цих природних агроландшафтів (позначено як ПА1 і ПА2) представлено в табл. 1.

16 Перельман А.И. Геохимия ландшафтов. Москва : Высшая школа, 1975. С. 22-23 ; Морозова И.А. Геохимические ландшафты и экологическая опасность. Прикладная геохимия. 2001. Вып. 1. Геохимическое картирование. С. 124. 
Таблиця 1

Ранжовані ряди поширення P, Ca, Zn, Co, Мо у компонентах природних агроландшафтів Правобережного Лісостепу

\begin{tabular}{|c|c|c|c|c|}
\hline \multirow{2}{*}{$\begin{array}{c}\text { Ланки } \\
\text { біогеохімічних } \\
\text { ланцюгів }\end{array}$} & \multicolumn{2}{|c|}{$\begin{array}{c}\text { Ранжовані ряди елементів } \\
\text { за фоновими значеннями } \\
\text { (у мг/кг) }\end{array}$} & \multicolumn{2}{|c|}{$\begin{array}{l}\text { Ранжовані ряди } \\
\text { елементів за Ax }\end{array}$} \\
\hline & ПА 1 & ПА 2 & ПА 1 & ПА 2 \\
\hline $\begin{array}{c}\text { злакове різнотрав'я } \\
\text { та різнотрав'я }\end{array}$ & $\begin{array}{c}\mathrm{Ca}(15620)-\mathrm{P} \\
(10400)-\mathrm{Zn} \\
(33)-\mathrm{Mo}(13) \\
- \text { Co }(2)\end{array}$ & $\begin{array}{c}\mathrm{Ca}(54385) \\
-\mathrm{P}(10100) \\
-\mathrm{Zn}(38)- \\
\mathrm{Mo}(17)- \\
\text { Co }(0,5)\end{array}$ & $\begin{array}{l}\mathrm{P}(380)- \\
\mathrm{Mo}(263) \\
-\mathrm{Ca}(23) \\
-\mathrm{Zn}(7)- \\
\mathrm{Co}(5)\end{array}$ & $\begin{array}{c}\text { Mo }(297) \\
-\mathrm{P}(182) \\
-\mathrm{Ca} \\
(60)- \\
\mathrm{Zn}(7)- \\
\mathrm{Co}(0,5) .\end{array}$ \\
\hline $\begin{array}{c}\text { грунти лучно- } \\
\text { чорноземні і } \\
\text { чорноземи типові } \\
\text { оглеєні (горизонт Нd) }\end{array}$ & $\begin{array}{l}\mathrm{Ca}(8600)-\mathrm{P} \\
(665)-\mathrm{Zn} \\
(46)-\mathrm{Mo}(8) \\
-\mathrm{Co}(6)\end{array}$ & $\begin{array}{c}\mathrm{Ca}(7950) \\
-\mathrm{P}(825)- \\
\mathrm{Zn}(44)- \\
\mathrm{Co}, \mathrm{Mo}(7)\end{array}$ & \multirow{2}{*}{\multicolumn{2}{|c|}{ Не визначається }} \\
\hline $\begin{array}{c}\text { грунтоутворюючі } \\
\text { породи суглинково- } \\
\text { супіщані }\left(a P_{I I I}\right) \mathrm{i} \\
\text { лесовані суглинки } \\
\left(v d, e P_{I I I}\right) \\
\end{array}$ & $\begin{array}{l}\mathrm{Ca}(6000)-\mathrm{P} \\
(1460)-\mathrm{Zn} \\
(39)-\mathrm{Co}(6,4) \\
-\mathrm{Mo}(5,8)\end{array}$ & $\begin{array}{c}\mathrm{Ca}(7950) \\
-\mathrm{P}(955)- \\
\mathrm{Zn}(43)- \\
\mathrm{Co}(7)- \\
\mathrm{Mo}(4)\end{array}$ & & \\
\hline
\end{tabular}

Порівняно 3 глобальними біосферними нормами (розд. 1) досліджені природні системи біогеохімічних ланцюгів Правобережного Лісостепу характеризують такі особливості. У ліву частину ранжованих рядів фонових значень агроландшафтів відносно рядів глобальних кларків переміщуються Мо - у грунтовому покриві та $\mathrm{Ca}-$ у різнотрав'яних фітоценозах, що вказує на відносно підвищений природний їх уміст у біогеохімічних ланцюгах цієї території. Відносно знижений природний уміст властивий відповідно Со - у грунтовому покриві та Р у різнотрав'яних фітоценозах, які зміщені у праві частини відносно відповідних глобальних ранжованих рядів. Природні особливості біологічного поглинання поживних елементів у ланцюгу «грунт - рослина» полягають у відносно підвищеному поглинанні Сa i зниженому поглинанні Zn різнотрав'яними фітоценозами.

Біогеохімічні коефіцієнти поживних елементів у компонентах досліджених природних агроландшафтів (позначено як ПА1 і ПА2) представлено в табл. 2. 
Таблиця 2

Біогеохімічні коефіціснти P, Ca, Zn, Со, Мо у компонентах природних агроландшафтів Правобережного Лісостепу

\begin{tabular}{|c|c|c|c|c|c|c|c|c|c|c|}
\hline \multirow{3}{*}{$\begin{array}{c}\text { Ланки біогео- } \\
\text { хімічних } \\
\text { ланцюгів }\end{array}$} & \multicolumn{10}{|c|}{$\begin{array}{c}\text { Кларки концентрації (ККі) та коефіцієнти біологічного } \\
\text { поглинання (Ах) у знаменнику }\end{array}$} \\
\hline & \multicolumn{2}{|c|}{$\mathbf{P}$} & \multicolumn{2}{|c|}{$\mathbf{C a}$} & \multicolumn{2}{|c|}{ Zn } & \multicolumn{2}{|c|}{ Mo } & \multicolumn{2}{|c|}{ Co } \\
\hline & $\begin{array}{c}\text { ПA } \\
1\end{array}$ & $\begin{array}{c}\text { ПA } \\
2\end{array}$ & $\begin{array}{c}\Pi \mathbf{A} \\
1\end{array}$ & $\begin{array}{c}\Pi \mathbf{H A} \\
2\end{array}$ & $\begin{array}{c}\Pi A \\
1\end{array}$ & $\begin{array}{c}\text { ПA } \\
2\end{array}$ & $\begin{array}{c}\Pi \mathbf{A} \\
\mathbf{1}\end{array}$ & $\begin{array}{c}\Pi \mathbf{H A} \\
\mathbf{2}\end{array}$ & $\begin{array}{c}\Pi \mathbf{A A} \\
\mathbf{1}\end{array}$ & $\begin{array}{c}\Pi \mathbf{H A} \\
2\end{array}$ \\
\hline $\begin{array}{c}\text { злакове } \\
\text { різнотрав'я та } \\
\text { різнотрав'я }\end{array}$ & $\frac{0,2}{380}$ & $\underline{0,1}$ & $\frac{0,5}{23}$ & $\frac{1,8}{60}$ & $\frac{0,04}{7}$ & $\frac{0,04}{7}$ & $\underline{0,6}$ & $\underline{0,8}$ & $\frac{0,1}{5}$ & $\frac{0,03}{0,5}$ \\
\hline $\begin{array}{c}\text { грунти лучно- } \\
\text { чорноземні і } \\
\text { чорноземи } \\
\text { типові оглеєні } \\
\text { (горизонт Нd) }\end{array}$ & 0,8 & 1,0 & 0,6 & 0,5 & 0,5 & 0,5 & 7 & 5,6 & 0,8 & 0,9 \\
\hline $\begin{array}{c}\text { грунтоутворю } \\
\text { ючі породи } \\
\text { суглинково- } \\
\text { супіщані ( } a P \\
\text { III) і лесовані } \\
\text { суглинки (vd,e } \\
\left.P_{I I I}\right)\end{array}$ & 2,4 & 1,6 & 0,2 & 0,3 & 0,4 & 0,5 & 3,8 & 2,8 & 0,3 & 0,4 \\
\hline
\end{tabular}

Природна система біогеохімічного ланцюга Р функціонує в умовах його фізико-хімічної концентрації у підстильних і грунтоутворюючих гірських породах (ККі $\geq 1,6)$ та біогенному розсіюванні у різнотрав'яних фітоценозах $(К К i \leq 0,2)$. Врівноважена міграція $\mathrm{P}$ у грунтах та зниження ролі у фітоценозах за фоновими значеннями узгоджуються 3 підвищенням до п'яти раз біологічного поглинання фосфору природними фітоценозами відносно норми для континентальних рослин $-\mathrm{Ax}=182-380$ при КПх $=52-70$.

Природна система біогеохімічного ланцюга Са функціонує в умовах його фізико-хімічного розсіювання у грунтоутворюючих гірських породах і грунтах $(\mathrm{KКi} \leq 0,6)$ та диференційованій біогенній міграції (від розсіювання до концентрації) у різнотрав'яних фітоценозах $(\mathrm{KKi}=0,5-1,8)$. Зростання ролі Са у ранжованих рядах фітоценозів (порівняно з фосфором) узгоджується зі стрімким зростанням до 60 раз його біологічного поглинання порівняно 3 біосферною нормою $\mathrm{Ax}=23-60$.

Природна система біогеохімічного ланцюга Zn функціонує в умовах його фізико-хімічного розсіювання у грунтоутворюючих гірських породах і грунтах $(K К i \leq 0,5)$ та інтенсивного біогенного розсіювання у різнотрав'яних фітоценозах (ККі $\leq 0,1)$. Розсіювання і зниження біологічної ролі $\mathrm{Zn}$ узгоджуються з падінням рівня його біологічного 
поглинання до двох раз порівняно з біосферною нормою $-\mathrm{Ax}=7$ за КПх $=42-66$.

Природна система біогеохімічного ланцюга Мо функціонує в умовах його фізико-хімічної концентрації у грунтоутворюючих гірських породах і грунтах $(\mathrm{KKi} \geq 1,6)$ та рівноважної біогенної міграції у різнотрав'яних фітоценозах $(\mathrm{KKi}=0,6-0,8)$. Концентрація та зростання ролі Мо у грунтах узгоджуються зі зростанням до 17 разів його біологічного поглинання порівняно 3 континентальними рослинами $-\mathrm{Ax}=263-297$.

Природна система біогеохімічного ланцюга Со функціонує в умовах його фізико-хімічного розсіювання у грунтоутворюючих гірських породах $(\mathrm{KKi} \leq 0,4)$ та інтенсивного біогенного розсіювання у різнотрав'яних фітоценозах (KКi $\leq 0,1)$. Урівноважений характер фізико-хімічної міграції Со у грунтовому покриві узгоджується 3 диференційованим характером його біологічного поглинання від двох разів нижче до шести разів вище від норми для континентальних рослин $-\mathrm{Ax}=0,5-5$.

Кореляційний аналіз особливостей біологічного поглинання біофільних елементів (Zn, P, K, Ca, Mn, Cu, As, Mo, Sr) у системі «грунт - рослина» у природних біогеохімічних ланцюгах свідчить про їх пряму лінійну кореляцію 3 глобальними нормами $A x$ для континентальних рослин - значення парних коефіцієнтів кореляції становлять $r=0,6-0,9$. Водночас для групи елементів-біофобів (Ti, V, $\mathrm{Cr}, \mathrm{Co}, \mathrm{Ni}, \mathrm{Zr}, \mathrm{Pb}$ ) природних ланцюгів лінійний зв'язок із глобальними оцінками $\epsilon$ зворотним $(r=-0,5)$. Кореляційний аналіз впливу на природне біологічне поглинання досліджених поживних елементів фізико-хімічного стану поверхневих вод ( $\mathrm{pH}$, іонна сила, мінералізація) та агрохімічних властивостей грунтів ( $\mathrm{pH}$, вміст гумусу) свідчить про таке. Біологічне поглинання рослинами фосфору і кобальту зворотним чином залежить від $\mathrm{pH}$ вод $(r=-0,7)$, кальцію - зворотним чином від $\mathrm{pH}$ грунту $(r=-0,9)$, молібдену - прямим чином від $\mathrm{pH}$ вод $(r=0,7)$ та зворотним чином від коефіцієнта іонної сили вод $(r=-0,5)$.

\section{2. Техногенно-природні системи біогеохімічних ланцюгів поживних елементів}

Техногенно-природні системи біогеохімічних ланцюгів характеризують середня ступінь зміни природних процесів та переважно рівноважність між природним i техногенним рядами міграції хімічних елементів під час формування умов життєзабезпечення рослин, тварин, мікроорганізмів. На території Правобережного Лісостепу до таких агроландшафтів відносяться орні землі (рілля) та багаторічні насадження садів і виноградників. Дослідження 
систем техногенно-природних біогеохімічних ланцюгів поживних елементів проводилося у межах двох елементарних агроландшафтів.

1. Елювіальний агроландшафт ріллі слабонахиленого вододілу із зерновими культурами (зернова сівозміна), чорноземами типовими на лесованих суглинках у межах вирівняних і слабонахилених поверхонь лесових розчленованих рівнин (ТПА1).

2. Транселювіальний агроландшафт ріллі із зерновими культурами (зернова сівозміна), чорноземами типовими на лесованих суглинках у межах схилів лесових розчленованих височин (ТПА2).

Ранжовані ряди фонових значень та коефіцієнтів біологічного поглинання у компонентах цих техногенно-природних агроландшафтів (позначено як ТПА 1 і ТПА 2) представлено в табл. 3.

Таблиця 3

Ранжовані ряди поширення $\mathrm{P}, \mathrm{Ca}, \mathrm{Zn}, \mathrm{Co}$, Мо у компонентах техногенно-природних агроландшафтів Правобережного Лісостепу

\begin{tabular}{|c|c|c|c|c|}
\hline \multirow{2}{*}{$\begin{array}{c}\text { Ланки } \\
\text { біогеохімічних } \\
\text { ланцюгів }\end{array}$} & \multicolumn{2}{|c|}{$\begin{array}{c}\text { Ранжовані ряди елементів за } \\
\text { фоновими значеннями (у мг/кг) }\end{array}$} & \multicolumn{2}{|c|}{$\begin{array}{l}\text { Ранжовані ряди } \\
\text { елементів за Ах }\end{array}$} \\
\hline & ТПА 1 & TПА 2 & ТПА 1 & ТПА 2 \\
\hline овес, колос & $\begin{array}{c}\mathrm{P}(14700)-\mathrm{Ca} \\
(11400)-\mathrm{Zn} \\
(19)-\mathrm{Mo}(4) \\
- \text { Co }(3)\end{array}$ & $\begin{array}{c}\mathrm{Ca}(26700)-\mathrm{P} \\
(6733)-\mathrm{Zn}(23)- \\
\text { Mo }(2,3)-\mathrm{Co} \\
(0,5)\end{array}$ & $\begin{array}{c}\mathrm{P}(130)- \\
\mathrm{Ca}(30)- \\
\mathrm{Zn}(11)- \\
\mathrm{Mo} \\
\mathrm{Co}(8)\end{array}$ & $\begin{array}{c}\mathrm{P}(226)- \\
\mathrm{Ca}-\mathrm{Mo} \\
(40)-\mathrm{Zn} \\
(6)-\mathrm{Co} \\
(0,7)\end{array}$ \\
\hline овес, стебло & $\begin{array}{c}\mathrm{P}(13150)-\mathrm{Ca} \\
(10700)-\mathrm{Zn} \\
(16)-\mathrm{Mo}(3) \\
-\mathrm{Co}(2)\end{array}$ & $\begin{array}{c}\mathrm{Ca}(27700)-\mathrm{P} \\
(9350)-\mathrm{Zn}(19)- \\
\mathrm{Mo}(2,5)-\mathrm{Co} \\
(1,8)\end{array}$ & $\begin{array}{c}\mathrm{P}(88)- \\
\mathrm{Ca}(15)- \\
\mathrm{Zn}(6)- \\
\mathrm{Mo}, \mathrm{Co} \\
(3) \\
\end{array}$ & $\begin{array}{c}\mathrm{P}(143)- \\
\mathrm{Ca}(25)- \\
\mathrm{Mo}(20) \\
-\mathrm{Zn}, \mathrm{Co} \\
(5)\end{array}$ \\
\hline $\begin{array}{l}\text { гречка, стебло i } \\
\text { суцвіття }\end{array}$ & $\begin{array}{c}\mathrm{Ca}(77400)-\mathrm{P} \\
(13300)-\mathrm{Zn} \\
(70)-\mathrm{Mo}(1) \\
-\mathrm{Co}(0,5) \\
\end{array}$ & Нема даних & $\begin{array}{l}\mathrm{P}(235)- \\
\mathrm{Zn}(12)- \\
\mathrm{Mo}(6)- \\
\mathrm{Co}(0,5)\end{array}$ & $\begin{array}{l}\text { Нема } \\
\text { даних }\end{array}$ \\
\hline $\begin{array}{c}\text { грунти } \\
\text { чорноземи } \\
\text { типові } \\
\text { (горизонт Hd) } \\
\end{array}$ & $\begin{array}{c}\mathrm{Ca}(8000)-\mathrm{P} \\
(1265)-\mathrm{Zn} \\
(50)-\mathrm{Co}(8)- \\
\mathrm{Mo}(6,3) \\
\end{array}$ & $\begin{array}{c}\mathrm{Ca}(7500)-\mathrm{P} \\
(1890)-\mathrm{Zn}(50)- \\
\mathrm{Co}(8)-\mathrm{Mo}(7,3)\end{array}$ & \multirow{2}{*}{\multicolumn{2}{|c|}{ Не визначається }} \\
\hline $\begin{array}{c}\text { грунтоутворюю } \\
\text { чі породи } \\
\text { лесовані } \\
\text { суглинки } \\
\left(v d, e P_{I I I}\right)\end{array}$ & $\begin{array}{c}\mathrm{Ca}(29800)-\mathrm{P} \\
(2835)-\mathrm{Zn} \\
(41)-\mathrm{Co}(6,6) \\
-\mathrm{Mo}(6,3)\end{array}$ & $\begin{array}{c}\mathrm{Ca}(32400)-\mathrm{P} \\
(1675)-\mathrm{Zn}(44)- \\
\mathrm{Co}(7)-\mathrm{Mo}(6,8)\end{array}$ & & \\
\hline
\end{tabular}


Порівняно 3 глобальними біосферними нормами (розд. 1) досліджені техногенно-природні системи біогеохімічних ланцюгів Правобережного Лісостепу характеризують такі особливості. У ліву частину ранжованих рядів фонових значень агроландшафтів відносно рядів глобальних кларків переміщуються лише $\mathrm{Ca}-\mathrm{y}$ зерні і стеблі вівса, а також надземній частині гречки. Така ознака зростання ролі кальцію та зниження ролі фосфору у зернових агрофітоценозах співпадає з особливостями фітоценозів природних біогеохімічних систем, тому має відноситься до природних особливостей агроландшафтів орних земель. Порівняно з природними системами у грунтах знижується роль Мо та зростає роль Со. Природно-техногенні особливості біологічного поглинання поживних елементів у ланцюгу «грунт - зернова культура» полягають у підвищеному поглинанні Са за зниженого поглинання Мo i Zn, серед яких зниження біологічного поглинання Мо можна віднести до агротехногенних деформацій.

Біогеохімічні коефіцієнти поживних елементів у компонентах досліджених техногенно-природних агроландшафтів (позначено як ТПА 1 і ТПА 2) представлено в табл. 4.

Таблиця 4

Біогеохімічні коефіціснти P, Ca, Zn, Co, Мо у компонентах техногенно-природних агроландшафтів Правобережного Лісостепу

\begin{tabular}{|c|c|c|c|c|c|c|c|c|c|c|}
\hline \multirow{3}{*}{$\begin{array}{c}\text { Ланки } \\
\text { біогео- } \\
\text { хімічних } \\
\text { ланцюгів }\end{array}$} & \multicolumn{10}{|c|}{$\begin{array}{c}\text { Кларки концентрації (ККі) } \\
\text { та коефіцієнти біологічного поглинання (Ах) у знаменнику }\end{array}$} \\
\hline & \multicolumn{2}{|c|}{$\mathbf{P}$} & \multicolumn{2}{|c|}{$\mathrm{Ca}$} & \multicolumn{2}{|c|}{$\mathrm{Zn}$} & \multicolumn{2}{|c|}{ Mo } & \multicolumn{2}{|c|}{ Co } \\
\hline & $\begin{array}{l}\text { TII } \\
\text { A } 1\end{array}$ & $\begin{array}{l}\text { TI } \\
\text { A } 2\end{array}$ & $\begin{array}{l}\text { TII } \\
\text { A } 1\end{array}$ & $\begin{array}{l}\text { TII } \\
\text { A } 2\end{array}$ & $\begin{array}{l}\text { TI } \\
\text { A 1 }\end{array}$ & $\begin{array}{l}\text { TI } \\
\text { A } 2\end{array}$ & $\begin{array}{l}\text { TI } \\
\text { A } 1\end{array}$ & $\begin{array}{l}\text { TI } \\
\text { A } 2\end{array}$ & $\begin{array}{l}\text { TI } \\
\text { A } 1\end{array}$ & $\begin{array}{l}\text { TI } \\
\text { A } 2\end{array}$ \\
\hline овес, колос & $\frac{0,2}{130}$ & $\frac{0,1}{226}$ & $\frac{0,4}{30}$ & 0,9 & $\frac{0,02}{11}$ & $\frac{0,03}{6}$ & $\frac{0,2}{8}$ & $\frac{0,1}{40}$ & $\frac{0,2}{8}$ & $\frac{0,03}{1}$ \\
\hline $\begin{array}{c}\text { овес, } \\
\text { стебло }\end{array}$ & $\frac{0,2}{88}$ & $\frac{0,1}{143}$ & $\frac{0,4}{15}$ & $\frac{0,9}{25}$ & $\frac{0,02}{6}$ & $\frac{0,02}{5}$ & $\frac{0,2}{3}$ & $\frac{0,1}{20}$ & $\frac{0,1}{3}$ & $\frac{0,1}{5}$ \\
\hline $\begin{array}{l}\text { гречка, } \\
\text { стебло і } \\
\text { суцвіття }\end{array}$ & $\frac{0,2}{235}$ & н.в. & $\frac{2,6}{\text { H.в. }}$ & н.в. & $\frac{0,1}{12}$ & н.в. & $\frac{0,04}{6}$ & н.в. & $\frac{0,03}{0,5}$ & Н.В \\
\hline $\begin{array}{c}\text { грунти } \\
\text { чорноземи } \\
\text { типові } \\
\text { (горизонт } \\
\text { Нd) } \\
\end{array}$ & 1,6 & 2,4 & 0,5 & 0,5 & 0,6 & 0,6 & 5,3 & 6 & 0,9 & 1 \\
\hline $\begin{array}{c}\text { грунтоутво } \\
\text { рюючі } \\
\text { породи } \\
\text { лесовані } \\
\text { суглинки } \\
\left(v d, e P_{I I I}\right)\end{array}$ & 4,7 & 2,8 & 1,0 & 1,1 & 0,4 & 0,5 & 4,2 & 4,5 & 0,4 & 0,4 \\
\hline
\end{tabular}


Техногенно-природна система біогеохімічного ланцюга Р функціонує в умовах його фізико-хімічної концентрації у підстильних $\mathrm{i}$ грунтоутворюючих гірських породах та грунтах $(\mathrm{KКi} \geq 1,6)$ за біогенного розсіювання у зернових культурах $($ КК $\leq 0,1)$. Зниженням ролі фосфору у агрофітоценозах узгоджується зі зростанням його біологічного поглинання до трьох разів порівняно з глобальною нормою - $\mathrm{Ax}=88-235$ при КПх $=$ 54-71. Порівняно 3 природними системами різнотрав'яних фітоценозів біологічне поглинання фосфору знижує інтенсивність до двох разів для гречки і понад чотири рази для вівса.

Техногенно-природна система біогеохімічного ланцюга Са функціонує в умовах його врівноваженої фізико-хімічної міграції у грунтоутворюючих гірських породах і грунтах $(\mathrm{KKi}=0,5-1,0)$ та диференційованій біогенній міграцій у зернових культурах $($ ККі $=0,4-2,6)$, що коливається від розсіювання для вівса до концентрації у гречці. Зростання ролі Са порівняно 3 фосфором за ранжованими рядами елементів у агрофітоценозах узгоджується зі зростанням його рівня біологічного поглинання до 30 разів у зерні та стеблі вівса порівняно з глобальними нормами $-\mathrm{Ax}=15-30$. Порівняно з природними системами різнотрав'яних фітоценозів біологічне поглинання кальцію знижує інтенсивність до чотирьох разів для стебла вівса.

Техногенно-природна система біогеохімічного ланцюга $\mathrm{Zn}$ функціонує в умовах його слабкого фізико-хімічного розсіювання у грунтоутворюючих гірських породах $\mathrm{i}$ грунтах $($ ККi $\leq 0,6)$ та інтенсивного біогенного розсіювання у зернових культурах $($ ККі $\leq 0,1)$. Слабке розсіювання $\mathrm{Zn}$ узгоджується 3 природним рівнем його біологічного поглинання гречкою $\mathrm{i}$ падінням до двох разів його біологічного поглинання для вівса $-\mathrm{Ax}=5-12$ за КПх $=19-116$. Порівняно 3 природними системами різнотрав'яних фітоценозів біологічне поглинання цинку підвищує інтенсивність до 1,7 рази для гречки.

Техногенно-природна система біогеохімічного ланцюга Мо функціонує в умовах його фізико-хімічної концентрації у грунтоутворюючих гірських породах і грунтах $(\mathrm{KKi} \geq 4,2)$ та біогенного розсіювання у агрофітоценозах $(\mathrm{KКi}=0,04-0,2)$. Зниження ролі Мо у грунтах та біогенне розсіювання у зернових культурах сполучаються 3 диференційованим характером його біологічного поглинання агрофітоценозами відносно глобальної норми $\mathrm{Ax}=3-40$. Порівняно з природними системами різнотрав'яних фітоценозів біологічне поглинання молібдену може знижувати інтенсивність майже до 100 разів.

Техногенно-природна система біогеохімічного ланцюга Со функціонуе в умовах його фізико-хімічного розсіювання у грунтоутворюючих гірських породах $(K К i \leq 0,4)$, рівноважної міграції у грунтах $(\mathrm{KКi}=0,9-1)$ та інтенсивного біогенного розсіювання 
у зернових культурах $($ ККі $\leq 0,1)$. Зростання ролі кобальту у грунтах в умовах його біогенного розсіювання сполучається як зростанням його біологічного поглинання до 10 разів вище від глобальної норми для вівса, так і зниженням до двох разів для гречки $-\mathrm{Ax}=0,5-8$. Порівняно 3 природними системами різнотрав'яних фітоценозів біологічне поглинання кобальту суттєво не відрізняється.

Кореляційний аналіз агрохімічних i фізико-хімічних показників техногенно-природних агроландшафтів 3 інтенсивністю біологічного поглинання Р і Со засвідчив відповідно позитивну $(\mathrm{r}=0,8)$ і негативну $(\mathrm{r}=-0,8)$ кореляцію 3 кислотно-лужним показником вод; біологічного поглинання $\mathrm{Zn}$ - негативну кореляцію із зольністю зернових культур $(\mathrm{r}=-0,6)$.

\section{ВИСНОВКИ}

В агросфері біогеохімічні ланцюги поживних елементів формуються під впливом природно-техногенних біосферних процесів i закономірностей. Структура агроландшафтів та умови їх функціонування зумовлюють динамічну рівновагу систем біогеохімічних ланцюгів різного співвідношення природних i техногенних (агротехногенних) процесів геохімічної міграції. Агроекологічне оцінювання таких систем базується на фонових рівнях умісту поживних хімічних елементів у компонентах агроландшафтів (гірські породи, води, грунти, природні фітоценози, сільськогосподарські культури) та оціночних коефіцієнтах біогенної і фізико-хімічної геохімічної міграції (Ах, ККі, КПх, ін.).

Досліджені природні та техногенно-природні системи біогеохімічних ланцюгів Правобережного Лісостепу займають значні площі земель сільськогосподарського призначення у межах сіножатей $\mathrm{i}$ пасовищ та орних земель із типовими чорноземами. Обом типам систем властиві переважно фізико-хімічна концентрація Р і Мо і розсіювання $\mathrm{Ca}, \mathrm{Zn}$, Со у гірських породах та грунтах за біогенного розсіювання цих поживних елементів у природних фітоценозах і зернових культурах. Між тим порівняльний аналіз природних i техногенно-природних систем біогеохімічних ланцюгів дав змогу виокремити агротехногенні деформації, які сформувалися в умовах існуючих тут заходів вирощування зернових культур, та рекомендувати запровадити нові заходи збалансованого природокористування. Суттєве зниження біологічного поглинання молібдену зерновими культурами (до 100 разів) потребує обробки рослин мікродобривом у період вегетації та свідчить про недоцільність включення у сівозміни культур зернобобових. Зниження біологічного поглинання фосфору і кальцію у культурі вівса (до чотирьох разів) визначає необхідність зміни існуючої 
системи внесення фосфорних добрив та недоцільність включення до сівозмін як зернобобових, так і овочевих культур.

\section{АНОТАЦІЯ}

Уведено поняття природних i техногенно-природних систем біогеохімічних ланцюгів для визначення особливостей поширення хімічних елементів в агроландшафтах. Агроекологічний аналіз систем включає оцінювання процесів біологічного поглинання, концентрації $\mathrm{i}$ розсіювання поживних елементів у сполучених компонентах систем. Досліджено поширення і міграцію $\mathrm{P}, \mathrm{Ca}, \mathrm{Zn}, \mathrm{Mo}$, Со у гірських породах, грунтах, природних фітоценозах та зернових культурах зональних агроландшафтів Правобережного Лісостепу. Установлено, що особливості геохімічної міграції низки елементів у гірських породах і грунтах у межах агроландшафтів орних земель зберігають природні особливості земель. Агротехногенні деформації техногенно-природних біогеохімічних ланцюгів проявлено у значному зниженні інтенсивності біологічного поглинання зерновими культурами $\mathrm{P}, \mathrm{Ca}$, Мо. Це визначає необхідність зміни існуючої системи внесення фосфорних добрив та недоцільність включення до сівозмін як зернобобових, так і овочевих культур.

\section{ЛITЕРАТУРА}

1. Созінов О.О. Агросфера України у XXI столітті. Вісник Національної академї̈ наук Украӥни. 2001. № 10. С. 7-16.

2. Ковальский В.В. Геохимическая экология. Москва : Наука, 1974. $298 \mathrm{c}$.

3. Сгорова Т.М., Ісаєнко В.М. Основи біогеохімії : навчальний посібник. Київ : НАУ, 2005. 166 с.

4. Сгорова Т.М. Екологічна геохімія агроландшафтів України : монографія / за наук. ред. О.І. Фурдичка. Київ : ДІА, 2018. 264 с.

5. Доспехов Б.А. Методика полевого опыта (с основами статистической обработки результатов исследований). Москва : Агропромиздат, 1985. $351 \mathrm{c.}$

6. Сгорова Т.М. Біогеохімічні пріоритети агроекологічних досліджень. Агроекологічний журнал. 2017. № 1. С. 28-35.

7. Иванов В.В. Экологическая геохимия элементов : справочник : в 6 кн. / под. ред. Э.К. Буренкова. Москва : Недра, 1994. Кн. 1. 304 с.

8. Кокин А.В., Слюсарь А.В., Шумакова Г.Е. Сохранение информации о первичной распространённости химических элементов на разных уровнях организации вещества. Достижения и проблемь современной науки : материалы XXII междун. науч.-практич. конф., г. Санк-Петербург, 4 августа 2017 г. Санкт-Петербург, 2017. С. 5-17. 
9. Перельман А.И. Геохимия ландшафтов. Москва : Высшая школа, 1975. $342 \mathrm{c}$.

10. Єгорова Т.М. Еколого-геохімічні процеси міграції кобальту в агроландшафтах України. Вісник аграрної науки. 2014. № 6. С. 58-63.

11. Комплект карт «Геологія i корисні копалини України», масштаб 1:1 000000 : пояснювальна записка / за ред. Д.Г. Гурського та ін. Київ : УкрДГРІ, 2003. 368 с.

12. Морозова И.А. Геохимические ландшафты и экологическая опасность. Прикладная геохимия. 2001. Вып. 1. Геохимическое картирование. С. 122-134.

\section{Information about the author:} Yehorova T. M., Doctor of Agricultural Sciences, Associate Professor at the Department of Ecology, Head of the Laboratory of Hydroecology Institute of Agroecology and Nature Management of National Academy of Agrarian Sciences of Ukraine 12, Metrolohichna str., Kyiv, 03143, Ukraine 